\title{
PSYCHOLOGICAL EMPOWERMENT PADA AGEN PERUBAHAN: STUDI KASUS DALAM ORGANISASI SEKTOR PUBLIK
}

\author{
Mimy Oktaviani dan Rayini Dahesihsari \\ Magister Psikologi Profesi Universitas Katholik Indonesia Atma Jaya \\ E-mail: mimyoktaviani@gmail.com
}

\begin{abstract}
ABSTRAK, Banyak penelitian menunjukkan bahwa proses perubahan tidak selalu memiliki dampak yang diharapkan jika tidak dikelola secara serius. Salah satu aktor kunci dalam mengelola proses perubahan adalah agen perubahan. Studi ini berfokus pada psychological empowerment kepada agen perubahan, yang diperlukan dalam peran mengatasi berbagai kendala dan kendala dalam memulai dan melaksanakan perubahan. Penelitian dilakukan di sektor publik di Jakarta menggunakan pendekatan kualitatif. Wawancara mendalam dilakukan di antara tiga karyawan organisasi yang ditunjuk sebagai anggota tim perubahan, untuk mengeksplorasi pengalaman mereka, penghargaan dan makna dari kompetensi yang mereka miliki untuk menerapkan perubahan serta mengatasi tantangan dan kendala. Hasil dari penelitian ini menunjukkan bahwa peserta menghargai peran mereka sebagai agen perubahan karena pengangkatan dari atasan mereka, merasa tugas ini adalah bagian dari mereka, dan melihat dampak positif dari peran mereka dalam membawa perubahan positif bagi organisasi. Mereka pada umumnya merasa cukup mampu melakukan peran mereka dengan cukup baik, meskipun masih membutuhkan pengembangan kapasitas berkelanjutan di seluruh proses perubahan yang sedang berlangsung. Mereka merasa bahwa mereka tidak dapat melakukan peran mereka secara optimal karena keterbatasan otoritas mereka. Keterampilan koordinasi yang baik diperlukan untuk kondisi ini sehingga setiap unit dapat didorong untuk mendapatkan perspektif yang lebih integratif tentang perubahan organisasi.
\end{abstract}

Kata Kunci: Perubahan Organisasi, Sektor Publik, Agen Perubahan, Psychological Empowerment

\section{PSYCHOLOGICAL EMPOWERMENT OF AGENT OF CHANGE: CASE STUDY IN PUBLIC SECTOR ORGANIZATION}

ABSTRACT, Many studies indicate that the process of change does not always have the expected impact if it is not seriously managed. One of the key actor in managing the change process is the agent of change. This study focuses on the psychological empowerment of the agent of change, which is needed in the role of overcoming various obstacles and constraints in initiating and implementing change. The study was conducted in a public sector in jakarta using a qualitative approach. In-depth interviews were conducted among the three employees of the organization who were appointed as the member of a team of change, to explore their experience, appreciation, and meaning of the competencies they possess to implement the changes as well as overcoming the challenges and constraints. The result of this research shows that the participant appreciates their role as an agent of change because of the appointment from their superiors, feels this task is part of them and sees the positive impact of their role in bringing positive change to the organization. They generally feel quite capable of performing their role well enough, though it still requires continuous capacity development throughout the ongoing process of change. They feel that they can not perform their role optimally because of the limitations of their authority. A good coordination skill is required for these conditions so that every unit can be encouraged to get a more integrative perspective about organizational change

Key words: organizational change, public sector, agent of change, psychological empowerment

\section{PENDAHULUAN}

Perubahan organisasiterjadi disetiap organisasi, begitupula dalam sektor publik. Reformasi Birokrasi (RB) merupakan salah satu perubahan organisasi di lembaga pemerintahan secara nasional, yang terjadi karena krisis di Indonesia yang memaksa pemerintah melakukan reformasi di segala bidang. RB mulai dicanangkan pada tahun 1998 dan sulit untuk diterapkan sampai dengan tahun 2009. Menurut Osborne dan Gaebler (1992), salah satu kendala dalam perubahan birokrasi dalam sektor publik yaitu karena budaya organisasi yang birokratis dan kaku.

Struktur organisasi lembaga pemerintahan di Indonesia termasuk ke dalam tipe birokrasi yang menurut Robbins (2013) merupakan struktur organisasi yang memiliki tugas rutin tinggi, dilaksanakan dengan cara spesialisasi kerja, memiliki aturan formal dalam melaksanakan tugas kesehariannya, tugas dikelompokkan sesuai departemen-departemen, memiliki otoritas yang tersentralisasi, rentang kendali yang terbatas, dan pengambilan keputusan sesuai dengan rantai komando yang ada (top down). Dengan tipe seperti ini, sedikit dibutuhkan inovasi dalam pelaksanaan tugasnya (Robbins, 2013), hal ini menjadi suatu tantangan berat dalam melakukan perubahan organisasi. Perubahan akan berjalan dengan lambat dan banyak kepentingan yang ikut berperan serta di dalamnya.

Pada tahun 2010 pemerintah melalui kementerian PAN dan RB membentuk grand design RB untuk memberi pedoman teknis untuk melakukan perubahan. Adapun sasaran yang ingin dicapai yaitu: (1) Terwujudnya pemerintahan yang bersih dan bebas KKN; (2) Meningkatnya kualitas pelayanan publik kepada masyarakat; (3) Meningkatnya kapasitas dan akuntabilitas kinerja birokrasi. Adapun peru-bahan yang di-lakukan dalam RB yaitu pada 8 (delapan) area perubahan seperti manajemen perubahan, penguatan pengawasan, penguatan akuntabilitas, penataan dan penguatan organisasi, penataan tatalaksana, penataan sistem manajemen SDM, penataan peraturan perundang-undangan, peningkatan kualitas pelayanan publik.

Diantara ke-8 area tersebut, fokus perubahan terlihat pada area SDM dimana proporsi perubahan lebih besar dibandingkan 
area yang lain, peran dan fungsi PNS yang strategis yaitu sebagai pelaksana, pelayan publik dan pengelola pemerintah erta memiliki tantangan yang lebih besar karena adanya penyakit birokrasi yang sudah membudaya (Sutherland, 1983). Berdasarkan Palmer, dkk (2009) perubahan tersebut termasuk ke dalam perubahan second order karena perubahan dilakukan secara mendasar dan merubah semua aspek dalam tata kelol pemerintahan.

Untuk mengusung perubahan tersebut, dibentuklah agen perubahan Menurut Smither, Houston, \& McIntire (2016) agen perubahan yaitu orang yang betangeng jub dith nembing dilenbangkn, sikan untuk melakukan perubahan.

Smither, Houston \& McIntire (2016) menyatakan bahwa dalam setiap perubahan yang terjadi, akan menemui hambata atau resistensi. Oreg et al (2011 dalam Smither, dkk, 2016) menyatakan bahwa terdapat beberapa resistensi dari sisi individ dan organisasi. Begitu pula yang dihadapi oleh agen perubah di lembaga pemerintahan yang harus menghadapi resistensi dar sisi organisasi berupa sistem kerja birokrasi yang sulit untuk menerima inovasi atau perubahan, RB merupakan perubahan yang berasal dari luar kementerian sehingga membutuhkan penyesuaian, selain itu terdapat ego sektoral dari unit di delam $k$ menterian terhadap perubahan tersebut.

Resistensi dari sisi individu berasal dari pegawai dan pejabat tinggi. Pegawai yang sudah bekerja puluhan tahun merasa nyaman dengan sistem sebelumnya sehingga enggan ntuk berubah. Selain itu,mereka juga merasa tidak memil kemampuan untuk mengikuti perubahan. Dari pihak pejabat, mereka menilitagen kurang melaksanakan perubahan RB. Selain itu, banyak pimpinan yang sudah pensiun dan penggantinya tidak paham tentang perubahan RB. Menurut Oreg dan Sverdlik (2011 dalam Smither, Houston \& McIntire (2016)), agen perubahan dapat dikataka bekerja secara efektif apabila mampu menghadapi resistensi atau membuat situasi yang tidak jelas menjadi suatu hal yang dap dilaksanakan.

Berdasarkan Smither, Houston \& McIntire (2016), terdapat beberapa kualitas yang diperlukan oleh agen perubahan dalam melaksanakan perubahan organisasi yaitu memiliki pusat kontrol internal, percaya bahwa dirinya memiliki kompetensi yang dibutuhkan, terbuka terhadap hal baru, toleransi yan ggi terhadap ketidakpastian, dan mau menanggung resiko. Hal tersebut di atas dapat dimiliki jika memiliki psychological empowerment.

Berdasarkan hasil penelitian yang dilakukan oleh Bowen dan Lawler (1992) psychological empowerment terbuk berkaitan dengan efektivitas dan inovasi dalam situasi kompleks, ketidakpastian dan minimnya peran manager. Thomas dan Velthouse (1990) menyatakan bahwa psychological empowermen akan dapat meningkatkan konsentrasi, inisiatif dan daya taha seseorang sehingas meningkatkan efetivitas kerj. Teer lencan masa kerjanya, agen pi deng 2025 sching dip pich

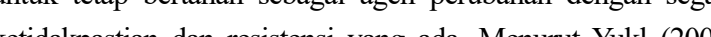
ketidakpastian dan resistensi yang ada. Menurut Yukl (2005) komitmen seseorang akan semakin kuat untuk menyelesaikan tugasnya jika memiliki psychological empowerment yang tingg. Agen perubahan diharapkan mampu untuk memilik inovasi dan mampu mengatasi resistensi yang ada. Tetapi sayangnya, hal tersebut kurang tampak pada agen perubahan lembaga pemerintahan dimana mereka tampak menyerah saa menghadapi resistensi yang ada karena merasa tidak memilik kewenangan dalam melakukan perubahan. Akhir-akhir in mereka juga merasa apatis dalam menghadapi resistensi yang ditemui. Mereka hanya menialani tugasnya sesuai pola pening dri le dir $\mathrm{RB}$, nyata terjadi dilapangan tidak sesuai dengan dokumen yang ada. Selain itu, pada tahun 2017 , mereka tidak dapat mencap target perubahan yang ditetapkan. Hal tersebut mencerminkan kurangnya psychological empowerment pada agen perubahar di lembaga pemerintahan sehingga kinerjanya tidak optimal da berdampak pada ketidakberhasilan dalam mencapai target.

\section{Psychological Empowermen}

Thomas dan Velthouse (1990 dalam spreitzer 1995) beranggapan bahwa psychological empowerment merupakan suatu konsep yang terdiri atas beberapa hal, sehingga bukan dianggap sebagai konsep tunggal. Thomas dan Velthouse (1990 dalam spreitzer 1995) menyatakan bahwa meningkatnya motivasi secara instrinsik akan mencerminkan orientasi individ pada peran kerjanya

Thomas dan Velthouse (1990) menyatakan terdapat 4 (empat) dimensi kognitif dalam hal kebermaknaan (meaning), kompetensi (competence), determinasi diri (self determination), dan pengaruh (impact). Berikut adalah penjelasan dari masingmasing dimensi yaitu:

a. Meaning,

Meaningmerupakannilaidaritujuan pekerjaan yangterkait dengan idealisme atau standar individu. Meaning membutuhkan kesesuaian antara peran di pekerjaannya dengan kepercayaan nilai yang dimilikinya dan tingkah laku. Kebermaknaan terkait dengan standar pribadi atau standar kebutuhannya

b. Competence,

Kompeten atau selfefficacy merupakan kepercayaan individu atas kemampuan dirinya sendiri dalam melakukan suat aktivitas dengan menggunakan keahlian yang mereka miliki Hal ini sejalan dengan istilah agency beliefs, suatu keahlian yang dimiliki dan harapan dari upaya yang telah diberikan (Bandura, 1989). Dimensi ini diberikan label kompeten dibandingkan seff esteem karena berfokus pada efficacy dalam area pekerjaan saja, bukan efficacy secara global.

\section{c. Self-determination,}

Adalah suatu perasaan memiliki kewenangan dalan membuat pilihan atau melakukan suatu pekerjaan. Hal in mereffleksikan otonomi dalam memulai atau melanjutkan suat pekerjaan. Hal ini juga terkait dengan tanggung jawab atas tindakan yang berhubungan dengan pekerjaannya.

d. Impact.

Impact atau dampak adalah derajat dimana seseorang merasa sejauh mana dirinya dapat mempengaruhi suatu hasil pekerjaan.

Secara bersamaan, keempat dimensi tersebut merefleksikan orientasi terhadap pekerjaannya secara aktif. Hal tersebut ter-gabung untuk membentuk satu konstruk yait pemberdeyan psikologis, atou dengan kata lain yaitu apabil pabila peris

\section{Tujuan Penelitian}

a. Mendapatkan gambaran psychological empower-men pada agen perubahan kementerian $P$.

b. Membuat rancangan intervensi yang sesuai dengan gambaran psychological empowerment agen perubahan tersebut.

\section{METODE}

Penelitian ini menggunakan pendekatan kualitatif karena mendapatkan data tent penaknaan, penghayatan 作 jalankan dalam reformasi birokrasi di Kementerian P, yan mengacu pada psychological empowerment mereka.

\section{Variabel Penelitian}

Definisi konseptual dari psychological empowerment adalah keyakinan yang dimiliki oleh seseorang untuk nelaksanakan perannya dalam suatu organisasi (Spretizer, 2007)

Definisioperasionalnyayaitu:(1) Meaningyaitu gambaran bagaimana partisipan memaknai dirinya sebagai agen perubahan RB. (2) Competence yaitu gambaran keyakinan partisipan atas kemampuan yang dimilikinya sehingga dapat melaksanakan (3) (a) (3) Seff der (5) sebagai agen perubahan. (4) Impact yaitu pandangan partisipan mengenai hasil kerja saat melaksanakan tugas sebagai age perubahan RB

\section{Partisipan Penelitian}

Kementerian $\mathrm{P}$ membuat fokus perubahan RB di area SDM sejalan dengan fokus perubahan RB nasional.

b. Termasuk dalam tim RB area perubahan SDM.

Proporsi perubahan RB paling besar berada di area SDM jika dibandingkan dengan area perubahan lainnya karena PNS memiliki peran dan fungsi strategis dalam menjalankan pemeintahan. Selain itu, tantangan dan resistensi lebih banyak ditemu di perubahan area SDM

Adapun jumlah partisipan dalam penelitian in sebanyak 3 orang karena tim RB area perubahan SDM hanya berjumlah 3 orang.Pengambilan data dengan menggunakan wawancara. Wawancara kualitatif dilakukan untuk memperoleh pengetahuan tentang makna subjektif yang dipahami individu berkenaan dengan topik yang diteliti dan peneliti bermaksud melakukan eksplorasi terhadap isu tersebut (Banister, et.ad 1994 dalam Poerwandari, 2017). Analisa menggunakan conten analysis dengan cara melakukan identifikasi, pengkodean dan kategorisasi.

\section{HASIL DAN PEMBAHASAN}

\section{Meaning}

a. Seluruh responden menjadi agen perubahan karena pe nunjukan langsung pada jabatannya.

Meaning merupakan pemaknaan individu mengenai suatu pekerjaan yang dilakukannya. Keseluruhan responden bergabung menjadi agen perubahan karena penunjukkan langsung terhadap batannya. Mereka kemudian memaknai penugasannya terseb secara pribadi. Menurut $\mathrm{H}$, setiap tugas yang diberikan adala tantangan yang harus diselesaikan dengan tanggung Jawab. Apalagi hal tersebut adalah suatu hal yang baru. Hal tersebu yang menjadi motivasi dalam menjalankan tugasnya sebaga gen perubahan secara optimal. Selain itu, dengan bergabung menjadi agen perubahan, ia berinteraksi dengan para pegawai Hal tersebut adalah situasi kerja yang disukainya sehingga in dapat merasa nyaman dalam bekeria

Awalnya A menjadi agen perubahan karena menjabat jabatan yang terkait dengan RB. Selanjutnya, ia menganggap jebagai bukti kepercayaan seseoran erhadapnya yang harus dijaga dan dipertahankan sehingga arus dijalani dengan tanggung jawab penuh. Penghayatanny ni menjadi motivasi la juga tertantang pada tugas baru dan dapat berdampak luas.

S menjadi agen perubahan karena posisi jabatannya. Ia merasa ditantang untuk membuat suatu perubahan, karena had tersebut merupakan salah satu tanggung jawab yang terka dengan jabatannya. Disini terlihat tidak ada keterlibatan pribad dengan agen perubahan sehingga dorongan untuk melakukan perubahan RB area SDM sebatas untuk menjalankan perannya sesuai posisinya

Berdasarkan hal tersebut di atas, terlihat bahwa $\mathrm{H}$ dan A mengaitkan secara pribadi perannya sebagai agen perubahan, dangkan hal tersebut tidak terlihat di S. Pemaknaan terseb kan terkait dengan cara kerjanya dalam mengusung perubahan e depannya. Meaning ini akan terkait dengan kepedulia erhadap apa yang akan mereka lakukan dalam pekerjaan merek (Spreitzer, 1995; Thomas\&Velthouse, 1990).

b. Umumnya, fokus perubahan RB yaitu perubahan SDM dan tata pemerintahan.

Baik A ataupun S, menekankan perubahan di area SDM dan tata pemerintahan. Sedangkan $\mathrm{H}$ memiliki tujua perubahan RB sesuai aturan yang berlaku dan mendapatka yangan kinerja ketika tujuan RB tercapai. Hal tersebut yasar perubahan yang dilakukan oleh masing-masing partisipan

c. Hal dasar yang membuat partisipan masih hertaho menjadi agen perubahan terkait dengan pemaknaan masingmasing responden terhadap perannya. 
Agen perubahan akan menghadapi berbagai rintangan dalam mengawal perubahan RB. Terdapat perbedaan alas mengapa mereka bertahan di dalam agen peru-bahan tersebu. Sampai saat ini, $\mathrm{H}$ masih bertahan men-jadi agen perubah karena ada kepuasan bahwa hasil kerjanya diterima dan dilaksanakan oleh seluruh pegawai kementerian P. Dari kepuasan inilah, membuat $\mathrm{H}$ bertahan dan menjadi faktor pendorong $\mathrm{H}$ menjalankan perubahan walaupun menghadapi segala kendala

Pada saat ini walaupun A merasa ingin berhenti sebagi gen perubahan, ia tidek dapat melakukan itu kerena is meras con pco Dengan pen perbaho Deng pengaye mampu bertahan dan akan bangkit kembali ketika menghadapi permasalahan. Apabila ditambah dengan pemberian andil atau peran dalam suatu tugas baru, ia akan makin terdorong untur melaksanakannya dengan segenap jiwanya.

S tetap bertahan karena masih menjabat sebagai kepala XYZ yang memiliki peran dalam perubahan SDM. Keterkait yang ada adalah antara jabatannya dengan tugas tim RB, bukan keterkaitan pribadi dengan agen perubahan.

Self-Determination

a. Sebagian dari partisipan memiliki otonomi dalam menjalankan peran perubahan

Determinasi diri yaitu bagaimana penghayatan partisipan mengenai otonomikewenanganny dem menjonk cebagi laks laksanaan perubalan menjalankan perannya, ia akan tergantung pada perintah atasan terlebih dahulu karena sistem kerja yang topdown. Ia merasa tidak bisa melakukan sumu pekerjaan yang mentinthya efektif tanpa adanya arahan atau perintah dari atasan. Dengan adanya batasan sistem tersebut, ia menjadi kurang bekerja secara optim dan menimbun inovasi yang kerap muncul dari dirinya.

Berbeda dengan $\mathrm{H}, \mathrm{A}$ dan $\mathrm{S}$ memiliki otonomi dalam me-ngatur tugas dan tanggung jawabnya. A menjelaskan bahwa dalam menjalani perannya di perubahan RB area SDM, A lebih berperan sebagai koordinator dokumen perubahan di dalam lingkup kerianya Secara lebih luas di lingkup kementerian P, A memiliki pern sebagi penerema kebjokn yang dber, mimpin pout oleh

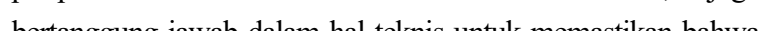
perubahan diketahui oleh seluruh pegawai melalui koordina dengan pihak terkait.

Begitu juga S, ia memiliki otonomi saat melak-sanakan peran sebagai agen perubahan. Peran yang dilakukan sebag agen perubahan terkait dengan pembuatan kebijakan da keputusan berdasarkan situsi dan kondisi yang sedang terja pemantauan proses perubahan, evaluasi yang dilakukan. Ia juga memiliki fungsi pembinaan dalam hal pemberian motivasi ataupun sanksi. Namun sayangnya, $\mathrm{S}$ terlihat kurang optimal dalam menjalankan perannya sebagai agen perubahan karena ia menjelankan RB berdsarkan tuntutan jabatan, sedangk perubahan RB adalah tugas tambahan dalam jabatannya

Dari hal ini bisa terlihat bahwa $\mathrm{H}$ memiliki keter-batasan dalam menjalankan perannya sehingga kurang optimal dalam bekerja. S juga menjadi kurang optimal karena perubahan RB
bukan tugas utama dari jabatannya sehingga mempengaruhi cara kerjanya walaupun ia memiliki otonomi penuh dalan menjalankan perannya. A dapat menjalankan perannya denga melihat kemungkinan-kemungkinan yang bisa ia lakukan karena dorongan dasarnya kuat dan memiliki otonom terhadap tindakan yang dilakukannya saat menjalani peran sebagai agen perubahan.

b. Seluruh partisipan merasa memiliki kewenangan yan terbatas yang menyebabkan performa kerja kurang optimal.

Seluruh partisipan merasa memiliki kewenangan yang terbatas oleh sistem kerja yang ada. H merasa dengan kewenangan yang terbatas seperti itu kurang dapat memfasilitasi dirinya dalam melakukan perubahan dan dapat mereduksi keyakinan bahw dirinya mampu dalam mengawal perubahan sehingga akhirnya bergantung pada pihak lain saat menjalankan perubahan. Menuru A, kewenangan atas perubahan RB area SDM berada di kepala biro kepegawaian dan tidak bisa didelegasikan, sehingga A meras terbatas kewenangannya pada saat menjalankan peran sebaga agen perubahan. Dengan posisi jabatannya ini, A merasa menjad agen perubahan adalah suatu hal yang berat untuk dilakukan karena tugasnya besar tapi kewenangannya terbatas sehinge membutulkn pejuangen untuk dopt mewujuknna. Da memba mi

Kewenangan S sebagai agen perubahan sesuai dengan kewenangan jabatannya karena perubahan SDM terkai dengan tugas pokoknya sehari-hari sehingga kewenangan in bisa digunakan untuk mempercepat proses perubahan. Namu pada pelaksanaannya, kewenangannya terbatas karena setia unit memiliki kewenangannya sendiri. Terkait dengan batasan kewenangan tersebut, semua partisipan menjadi kurang optima dalam bekerja. Menurut Spreitzer (1995), determinasi diri dapat membuat seseorang membuat pilihan yang rasional da mandiri dalam bekerja. Dan hal tersebut tidak terlihat pada ketiga partisipan, dimana $\mathrm{H}$ bersikap menyerahkan masa-la yang dihadapi ke atasannya karena merasa tidak bisa menyelesaikannya terkait dengan kewenangannya yang terbats A menjadi mas berat ken buth A A ter bahwa la tidak tahu apa yng harus dilakukannya terkait batasa kewenangan tersebut.

c. Seluruh partisipan menganggap bahwa koordinas adalah kunci menembus batasan kewenangan.

H masih mengupayakan sesuatu untuk menghadapi permasalahan yang ditemuinya. Pada saat ia tidak bisa menghadapi permasalahan tersebut, ia akan menggunakan jalur birokrasi ke atas untuk mendapatkan solusi kebijakan dari pimpinan. Selain itu, ia juga meng-gunakan koordinasi sebagai solus karena dianggap bisa menyelesaikan masalah

A juga menyelesaikan masalah yang dihadapinya yaitu dengan melakukan koordinasi dengan pihak terkait di XYZ dan membangun komitmen pimpinan karena pimpinan yans memiliki kewenangan penuh di areanya masing-masing dan memiliki peran penting dalam budaya PNS. Sampai saat ini, ia membutuhkan cara untuk bisa menggugah pimpinan unit lain dengan cara koordinasi.

S merasa bahwa solusi yang bisa dilakukan untuk menghadapi permasalahannya yaitu dengan membuat kebijakan sesuai situasi dan kondisi yang ada saja dan melakukan koordinasi dengan unit lain. Terkait dengan koordinasi, ia masih membutuhkan strategi untuk bisa memanfaatkan koordinasi dengan efektif.

Terdapat kesamaan solusi yang dianggap dapat me-nembus

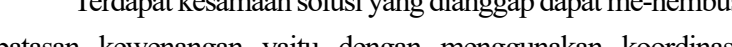

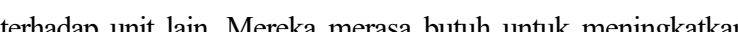
terhadap unit lain. Meta man strategi agar koordinasi sehingga dapat menembus batasan kewenangan yang ada. Tidak bs dipungkiri kalau setiap unit memiliki tugas dan kewenangannya secara otonom, sehingga diperlukan strategi
komunikasi yang tepat sehingga bisa meningkatkan koordinasi antar unit.

d. Seluruh partisipan merasa rekan kerja di XYZ memiliki efek positif dalam menyokong perubahan yang dilakukan oleh agen perubahan.

Seluruh partisipan merasa bahwa rekan kerja di XYZ memiliki semangat kerja ketika harus mengumpulkan data yang dibutuhkan. Kerjasama juga terjalin dengan baik sehingga dapat menyelesaikan permasalahan secara bersama-sama. Hal dapat menyelesaikan permasalahan secara bersama-sama.
ini dirasakan mendukung perjuangan yang sedang dilakukan ini dirasakan mendukung perjuangan yang sedang dilakukan
oleh agen perubahan dan menjadi energi tambahan dalam oleh agen perubahan dan menjadi energi tan
melaksanakan tugas dan menyelesaikan masalah.

\section{Competence}

a. Seluruh partisipan merasa memiliki kemampuan yang dapat mendukungnya untuk menjalankan peran sebagai agen perubahan

Competence yaitu keyakinan diri partisipan atas kemampuan yang dimilikinya sehingga dapat melak-sanakan tugas yang diemban dan mencapai tujuannya dengan sukses. Ketiga partisipan merasa memiliki kemampuan yang dibutuhkan untuk
mengawal perubahan RB area SDM, sehingga mereka memiliki keyakinan diri yang penuh bahwa mereka bisa menjalankan keyakinan diri yang penuh bahwa m.

Beberapa kutipan di atas merupakan kemampuankemampuan yang dimiliki oleh setiap partisipan yang dianggap dapat membantunya dalam menjalankan peran-nya masingmasing. Terkait dengan tugas sebagai agen perubahan yang kompleks dan harus menghadapi segala resistensi yang ada sehingga membutuhkan karakteristik yang kredibel, kompeten dan dapat dipercaya untuk dapat melalui hal tersebut dengan baik dan sukses membawa perubahan (Oreg \& Sverdlik, 2011). Tidak hanya kemampuannya yang dibutuhkan, keyakinan diri bahwa dirinya memiliki kemampuan tersebut dan menggunakannya juga merupakan faktor penting.

b. Seluruh partisipan merasa butuh untuk meningkatkan kemampuan di bidang tugasnya masing-masing

Sejalan dengan peran yang dilakukan, mereka membu- tuhkan kemampuan tertentu yang mendukungnya dalam menjalankan roda perubahan. H membutuhkan kemampua strategic thinking dan problem solving. A membutuhka komunikasi efektif terkait dengan perannya. S membutuhk leadership yang sesuai dengan generasi baru dan juga IT. Disini terlihat adanya keinginan untuk mengembangkan supaya bisa menjalankan tugas dengan lebih baik lagi.

c. Seluruh partisipan merasa butuh untuk melakukan aktivitas pengembangan diri

Seluruh partisipan merasa bahwa mereka membutuhkan kegiatan pengembangan diri yang dirasa efektif untuk dapat meningkatkan kemampuan yang dibutuhkannya masing-masing Secara umum, cara yang efektif untuk mengembangkan dirinya yaitu mengikuti training/pelatihan. $\mathrm{H}$ merasa membutuhkan aktivitas lain selain training seperti coaching ataupun feedback untuk dapat mengetahui kemampuan dirinya dan mengembangkannya.

Disini terlihat bahwa mereka menyadari kekurangan dir dan memiliki kebutuhan ke depan serta memiliki keinginan untuk mengembangkannya. Jadi keyakinan atas kemampuannya tidak menjadikannya merasa sempurna, tapi memiliki keinginan untuk terus berkembang.

Sampai saat ini, seluruh partisipan baru melakukan pengembangan sebatas pengembangan pengetahuan.

Namun ternyata dorongan untuk mengembangkan diri baru sebatas membuat mereka melakukan pengembangan pada level pengetahuan melalui membaca. H juga melakukan diskus dengan pihak lain, selain membaca. Seluruh partisipan belun ada yang melakukan aktivitas pengembangan lainnya untu meningkatkan kemampuan yang dibutuhkannya masing-masing

Impact

a. Sebagian responden merasa bahwa upayanya menghasilkan dampak yang signifikan bagi organisasi

Impact adalah pandangan mengenai hasil kerja saat melaksanakan tugas sebagai agen perubahan RB. Hal ini terkait dengan sejauh mana individu merasa bahwa dirinya telah berperan dengan baik sehingga menghasilkan dampak yang signifikan untuk organisasi. Hal ini akan terkait dengan kepuasan kerja individu tersebut.

H dan A merasa mampu memberikan dampak nyata yang signifikan bagi kementerian karena apa yang mereka lakukan dapat menghasilkan tunjangan kinerja yang dinantik oleh seluruh pegawai kementerian P. selain itu, index RB jug meningkat karena adanya perubahan yang lebih baik dan ketercapaian target. Sedangkan S merasa puas ketika mendapatkan hasil berupa penilaian ataupun penghargaan yang terkait dengan jabatannya, dimana hasil tersebut tidak berdampak langsung pada kementerian, tapi kepuasan pribad terkait jabatannya.

Hal ini tentunya akan membedakan dalam hal kepuasan yang dirasakan dan dorongan untuk melaksanakan tugas kedepannya. Hal ini juga terkait dengan pemaknaan mengenai agen perubahan itu sendiri. S yang menjalankan perubahan karena 
jabatannya, maka ia akan merasa cukup dengan hasil yang terkait dengan jabatannya saja. Berbeda dengan $\mathrm{H}$ dan $\mathrm{A}$ yan memaknai secara pribadi agen perubahan tersebut, sehingga mendorongnya untuk berusaha mendapatkan hasil yang signifikan bagi kementerian.

Dari hasil penelitian yang dilakukan, tampak bahwa psychological empowerment yang dimiliki oleh agen perubahan RB area SDM masih belum optimal. Pada dimensi meaning pada saat pekerian yang dijalani dikeittan dengan kebuthonnya

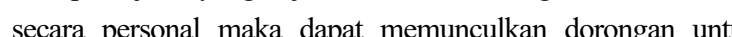
tecta bethe te

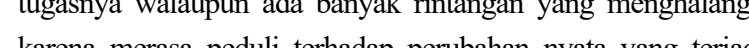
karena merasa peduli terhadap perubahan nyala yang terja di kementerian P. Hal tersebut sesuai dengan hasil penelitia dari Spreitzer (1995) dan Thomas \& Velthouse (1990) yang menyatakan bahwa ketika pekerjaan sesuai dengan diriny dikaitkan dengan dirinya, maka ia merasa bahwa pekerjaa tersebut penting dan akan menumbuhkan kepedulian terhada apa yang mereka lakukan ke depannya saat menjalani pekerjaan mereka.

Kanter (1993) menyatakan bahwa lingkungan kerja akan berhubungan dengan psychological empowerment pegawainya terutama pada dimensi self-determination. Dengan adanya keterbatasan sistem dari lingkungan kerja, membuat partisipan menjadi kurang dapat optimal dalam menjalankan tugas karena merasa tidak memiliki otonomi atau keleluasaan dalam bekerja (self-determination) dan kewenangan dalam melakukan sesuatu. Namun mereka masih mengusahakan cara lain untuk dapat menembus batasan-batasan yang ada melalui koordinasi.

Sampai saat ini mereka masih memikirkan strategi untuk membuat koordinasi menjadi makin efektif dalam mendukung peran mereka dalam membuat suatu perubahan di area SDM. Permasalahannya yaitu setiap unit berdiri sendiri dan memiliki tugas dan kewenangan sendiri secara otonom. Strategi yang dapat digunakan untuk menjembatani hal tersebut yaitu menggunakan Communication Accomodation Theory (CAT) dalam koordinasi yang dilakukan antara tim RB dengan unit kerja yang ada kementerian P. CAT adalah teori yang mensgambarkn pol . 2003 dalam Rosarini dan Dahesihsari, 2009).

Pada dimensi competence, para partisipan merasa memiliki kemampuan yang diperlukan untuk melakukan perubahan, sehingga membuat mereka yakin akan dapat menjalankan perannya dengan baik dan mencapai tujuan reformasi birokrasi. Thomas \& Velthouse (1990) menyatakan bahwa competence akan terkait dengan keyakinan individu akan kemampuannya dan sejauh mana individu dapat melakukan pekerjaan dengan menggunakan keterampilannya. Mereka juga memiliki keinginan untuk mengembangkan diri untuk lebih baik lagi sehingga dapat menjalankan perannya dengan lebih efektif.

Dimensi impact berhubungan dengan kepuasan kerja individu tersebut Hasil penelitian ini sejalan dengan penelitin sebelumnya dimana pade saat partisipan merasa memiliki an yang membuat dampak signifikan bagi kementerian, ia merasa lebih puas dengan hasil kerianya tersebu.

Secara umum, terlihat bahwa psychologicalempowerment tim RB area SDM kurang optimal sehingga butuh intervensi yang dilakukan peneliti untuk membantu meningkatkan psychologicul empowerment dalam menjalankan perannya. Melihat hal tersebut, intervensi yang bisa dilakukan untuk itu yaitu denga coaching sehingga bisa mengoptimalkan kinerja masing-masing partisipan. Menurut Grant (2001, dalam Yuliawan, 2011) coaching adalah proses yang berorientasi pada solusi dan hasil, dimana seorang coach memfasilitasi proses pembelajaran secara personal, pertumbuhan diri dan peningkatan kualitas hidu klien dalam lingkup yang ditentukan sendiri. Coaching dap per poni potnsi yng milhana, coaching akan menbant sescorang

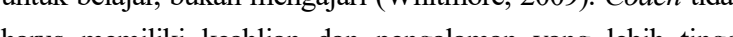
harus memiliki keahlian dan pengalaman yang lebih tingg daripada klien, karena coach memfasilitasi proses belajar, bukar yang mengajarkan (Hall dan Duval, 2004).

\section{SIMPULAN}

Secara umum, terdapat perbedaan pada dimensi meaning $\mathrm{d}$ ketiga partisipan. Dan terlihat kesamaan dari ketiga partisipan pada dimensi self-determination. Partisipan yang mengaitkan peran agen perubahan secara personal akan memiliki dorongan bekerja yang lebih dibandingkan hanya sekedar memenuh tuntutan tus. Batson pen beth a Ber pe

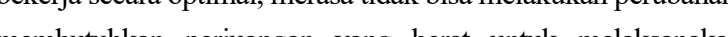
membutuhkan perjuangan yang berat untuk melaksanaka tugasnya, atau menyandarkan keputusan kepada pihak lain Solusi efektif untuk menembus batasan-batasan formal yang ad yaitu melalui koordinasi. Saat ini mereka masih membutuhka strategi untuk dapat memantapkan koordinasi yang menjad solusi mereka saat ini. Seluruh partisipan yakin bahwa merek memili-ki kemampuan yang dapat menunjangnya untuk melakukan perubahan. Dibutuhkan pengembangan yang berkelanjutan melalui berbagai aktivitas pengembangan diri. Namun sayangnya mereka baru melakukan pengembangan sebata pengembangan pengetahuan saja. Partisipan yang merass bahwa

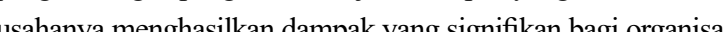

akan memunculkan kepuasan kerja.

\section{DAFTAR PUSTAKA}

Dahesihsari dan Rosarini. (2009). Strategi Komunikasi dalam Tim Kerjasama antar Divisi, Studi Kasus pada Tim Kerja Pemeliharaan Produk Perbankan. Jurnal Psikologi, vol 24, No. 2 September 2009. Indonesia.

Debora, D. (2007). Pengaruh Pemberdayaan Kerja dan Psikologis Terhadap Kepercayaan Organisasional dan Kepuasan Kerja Dosen Tetap Perguruan Tinggi Swasta Jurnal Manajemen dan Kewirausahaan, 8(2), 61-71.

Denhardt, J. V., \& Denhardt, R. B. (2007). The New Public Service, Expanded Edition: Serving, Not Steering. ME Sharpe, Incorporated.

Dewettinck, K., Singh, J., \& Buyens, D. (2003). Psychological empowerment in the workplace: Reviewing the empowerment effects on critical work outcomes (pp. 1-24). Vlerick Management School.

Kumar, R. (2011). Research methods: A step by step guide for beginners. 3rd rd Edition.

Luthans, F. (2011). Organizational behaviour: An evidencebased approach. McGraw-Hill.

Meyerson, G., \& Dewettinck, B. (2012). Effect of empowerment Economic and Management Sciences, 2(1), 40-46.

Ölcer, F., \& Florescu, M. (2015). Mediating effect of job satisfaction in the relationship between psychologet empowerment and job performance. Theoretical and Applied Economics, 22(3), 604
Osborne, D. (2007, June). Reinventing government: What a difference a strategy makes. In 7 th Global Forum on Reinventing Government: Building Trust in Government (pp. 26-27).

Palmer, I., Dunford, R., Akin, G. (2009). Managing Organizational Change. McGraw Hill: New York.

Poerwandari, Kristi. (2017). Pendekatan Kualitatif untu Pendekatan Perilaku Manusia. Depok: LPSP3.Robbins, PS., Judge AT. (2013). Organizational Behavior, 15th edition. Pearson: England. 